\title{
Factors Responsible for the Yield Gap in Vegetable Cultivation and Measures to Increase the Productivity in Tamil Nadu, India
}

\author{
A. Janaki Rani* \\ (Agrl.Extension), Department of Human Development and Family Studies \\ Community Science College and Research Institute, Madurai-625104, India \\ *Corresponding author
}

\begin{tabular}{l} 
K e y w o r d s \\
Vegetable crops, \\
Productivity, \\
$\begin{array}{l}\text { Factors for yield } \\
\text { gap, Physiological } \\
\text { disorder }\end{array}$ \\
Article Info \\
$\begin{array}{l}\text { Accepted: } \\
10 \text { August } 2020 \\
\text { Available Online: } \\
10 \text { September } 2020\end{array}$ \\
\hline
\end{tabular}

\section{Keywords}

Vegetable crops, Productivity, Factors for yield gap, Physiological disorder

Accepted:

Available Online:
10 September 2020

\section{A B S T R A C T}

The vegetable production in India is largely produced by small and marginal farmers from small scale subsistence level farming systems. Even at the time of producing the crops and at the time of selling them, they face a lot of hurdles and obstacles. Keeping this in view the study focus on the real factors responsible for the less productivity in vegetable crops and to give suitable measures. The research was conducted in Madurai district of Tamil Nadu, India with 90 respondents. Interview schedule was used for collecting data. Fruit borer $(70.00 \%)$, blossom dropping and less fruit setting percentage $(68.33 \%)$, sunscald $(61.66 \%)$, tomato cracking or split tomato problem $(53.33 \%)$, yellow or green tomato shoulders and deformation of tomato fruit $(51.66 \%)$ were the major biological factors for yield gap. With regard to brinjal the major problems are fruit and shoot borer (76.66\%), fruit rot /blossom end rot (40.00\%), brown streaking (36.66\%) and small size and unsized hard fruits $(30.00 \%)$. With regard to bhendi the major problems are fruit borer and powdery mildew $(50.00 \%)$. Bhendi curling/small size of fruit/discoloration and hardness $(40.00 \%)$ was expressed by the farmers which reduce the yield. Rise in fertilizer and pesticide prices, unavailability of timely and quality inputs, lack of knowledge to identify pest and diseases, lack of communication and training cum demonstrations on improved practices were felt by $35-45$ percent of the farmers as other factors for yield gap. Support of research and extension is necessary for narrowing the yield gap.

\section{Introduction}

Vegetables are an important nutritional requirement of human beings as vegetables not only cater the taste of our daily foods but also supply vitamins, minerals and disease preventing photochemical. India is second largest producer of vegetables in the world with annual estimated production of 162 million tonnes from an area of 9.2 million hectares having productivity of 17.3 tonnes/hectare (Sudhir Singh, 2015). Tamil Nadu state has nearly 3 per cent of vegetable cultivation area and 5 per cent of vegetable production of the country.

Even though the area is higher, the farmers who produce vegetable crops, struggle a lot to bring them up. Even at the time of producing the crops and at the time of selling them, they 
face a lot of hurdles and obstacles such as the interference of brokers and middlemen, lack of insurance facility, lack of finance, high cost of inputs, problems related to storage of the produce and transportation problems. Hence, large quantities of vegetables perish accounting to the loss of Rs. 500 billion annually.

Several factors can influence stand establishment in vegetable crop production. Environmental conditions such as soil physical characteristics, temperature and moisture, various cultural practices, and diseases may all be limiting factors in establishing maximum stands and achieving the highest possible yields. Soil solarisation kills the pathogen propagules and other resting structures in soil, leaves no toxic residue, mobilizes nutrient release by speeding up breakdown of organic matter in soil (Stapleton et al., 2000). It has been widely practiced for cultivation of vegetable crops as tomatoes, brinjal etc. Deep summer ploughing exposes the pathogenic propagules and other resting structure which are then killed by heat during hot summer months (Bennett, 1997). Rachnasingla (2016) indicated that lack of knowledge about IPM technologies $(81.66 \%)$ followed by seed treatment $(80.83 \%)$ and training on scientific vegetable production technology $(79.17 \%)$, lesser knowledge regarding critical stage of irrigation (69.17\%) and non- availability of facilities for soil testing $(66.67 \%)$ were the factors reducing yield. Support of research and extension is necessary for narrowing yield gap.

Keeping the above situations in mind, an attempt has been made to identify the real factors reducing the production and productivity are very essential to boost up the vegetable cultivation in order to stabilize the productivity and to ensure assured income to farmers in the rural areas. Hence, the present study was undertaken to assess the factors responsible for the yield gap and measures to overcome.

\section{Materials and Methods}

The study area for this project was Madurai district of TamilNadu, India. In this district chellampatti block was selected based on the highest area under vegetable cultivation. From the block@30 tomato, brinjal and ladies finger farmers were selected randomly to constitute the study of 90 respondents. Interview schedule was constructed, pre tested and finalized and used for collecting data. Relevant data collected pertaining to the study was analyzed, interpreted and meaningful conclusions were drawn using percentage analysis.

\section{Results and Discussion}

Factors reducing the productivity in major vegetable crops (Table 1-3)

\section{Biological and climatic factors reducing the productivity in major vegetable crops}

Several factors can influence the vegetable crop production. Environmental conditions such as soil physical characteristics, temperature and moisture, various cultural practices and diseases may all be limiting factors in establishing maximum stands and achieving the highest possible yields. With regard to tomato, it is observed from the table that, the intensity of pest and diseases and physiological problems due to climatic factors is increasing day by day. Apart from this climate change is also one of the inhibiting factors. Fruit borer $(70.00 \%)$, blossom dropping and less fruit setting percentage (68.33\%), Sunscald (61.66 \%), tomato cracking or split tomato problem (53.33\%), deformation of tomato fruit $(51.66 \%)$, yellow or green tomato shoulders $(46.66 \%)$, blossom 
end rot $(33.33 \%)$, hardness of fruit/ smaller size of fruit bearing $(30.00 \%)$ and tomato fruit zippering (26.66\%) were the major problems which leads to yield gap. This is in line with the findings of Kondinya Ayyogari (2014).

Nowadays, the infestation of pests due to climate change is increasing. Climate change influences the ecology and biology of insect pests. Hence, 70.00 percent of the farmers felt it as one of the reasons for the reduction in yield. Measures to counteract the soil and environmental constraints on seeds, and the use of appropriate seed treatments to aid in seedling emergence and pest and disease management are essential for vegetable crop production. Protecting the seed and seedlings from disease pathogens and using effective cultural practices like deep summer ploughing will lead to increase withstanding capacity and yields.

Secondly, they felt blossom dropping and less fruit setting $(68.33 \%)$ were the problems. The pre-anthesis temperature stress is associated with developmental changes in the anthers and pollen formation includes bud drop, abnormal flower development, poor pollen production, dehiscence, poor viability and other reproductive abnormalities. Other reasons for blossom drop on tomatoes are insect damage, lack of water, too much or too little nitrogen and lack of pollination. Hence, this was felt as important factor for yield gap.

The sunscald often especially prevalent when maturing fruit suddenly becomes exposed to the direct rays of the sun. Hence high temperatures caused significant losses in tomato productivity (61.66\%).

Fluctuation of temperatures and a lack of water and too much water after a dry spell cause the skin to split or tomato cracking. Hot, rainy weather also causes fruit crack. After a long dry spell, tomatoes are thirsty.
Plants may take up water rapidly after the first heavy rainfall, which swells the fruit and causes it to crack. Hence majority felt it as one of the factor for yield reduction (53.33\%). This is in line with the findings of Alam (2011). Physical damage to the blossom can also cause catfacing or deformation of fruits $(51.66 \%)$.

Yellow or green tomato shoulders are the result of high heat. The shoulder of a tomato is that soft rounded area at the top that borders the stem scar. Low levels of potassium in soil and alkaline $\mathrm{pH}$ levels are the reasons. Hence it was expressed by $46.66 \%$ of the farmers. Blossom end rot is a physiological disorder caused by a calcium imbalance within the plant, but, necrotic tissue can be easily colonized by fungi and bacteria, Hence it was expressed by $33.33 \%$ of the farmers.

Hardness of fruit/ smaller size of fruit bearing were felt by $(30.00 \%)$. Significant inhibition of photosynthesis occurs at temperatures above optimum, resulting in considerable loss in terms of reduced fruit set, smaller and lower quality fruits. Further, water greatly influences the yield and quality of vegetables; drought conditions, water scarcity, less irrigation drastically reduce vegetable size and productivity.

Tomato fruit zippering is a physiological disorder that causes a characteristic thin, vertical scar running from the stem of the tomato. This scar may reach the entire length of the fruit to the blossom end. This is also felt by the farmers $(26.66 \%)$. Farmers as a whole expressed that for every $15 \mathrm{~kg}$ of tomato fruits $3 \mathrm{kgs}$ are become waste due to this physiological disorders and pest and diseases.

With regard to brinjal the major problems are fruit and shoot borer and squirrel problem (76.66\%), fruit rot /blossom end rot $(40.00 \%)$, 
brown streaking $(36.66 \%)$ and small size and unsized hard fruits $(30.00 \%)$. With regard to bhendi the major problems are fruit borer and powdery mildew $(50.00 \%)$. Bhendi curling/Small size of fruit/discoloration and hardness $(40.00 \%)$ and increase in fibre content $(26.66 \%)$ were the other factors expressed by the farmers which reduce the yield.

These biological and climatic factors can be effectively addressed through an Integrated Crop Management (ICM) practices. Transfer of practices through extension agents could effectively help farmers minimize technology gaps and yield gaps, effective cultural practices like deep summer ploughing, seed priming, biological seed treatments, timely planting, proper seeding depth, irrigation, uniform fertilizer application, weeding, mulching, plant protection and timely harvesting could account for more than 20\% yield increase.

Deep summer ploughing exposes the pathogens and other resting structure which are then killed by heat during hot summer months. Seed priming which promotes rapid and uniform germination once the seeds are planted in the field and increases vigor and yields resulting in greater profits. Biological seed treatments improves physical properties of the seed for ease of handling, reduce pesticide dusts used on seeds, better protection against pest and disease.

Shallow planting may expose seeds to excessive temperatures, and uneven moisture. Proper seeding depth is important for allowing adequate moisture for the seed to germinate without exposing it to unnecessary environmental stresses. If the fertilizers are spread unevenly and inadequately to the crops it may affect crop yield. Hence, uniform spread is necessary. Use of plastic mulches can improve stands and yields by maintaining favorable soil moisture and temperature needed for seed germination and seedling growth. Timely harvest is very essential to get good yield.

The Resource-poor marginal and small farmers couldn't able to buy the required quantity of fertilizer and pesticide due to high cost and not applying right quantity and time and facing lower yield. Rise in prices was felt by 45.56 percent of the farmers as one of the hindering factors for the reduction in yield. These farmers need to be supported by adequate and timely supply of quality inputs to narrow yield gaps. Hence the unavailability of timely and quality inputs was felt by 42.22 percent of the farmers.

Lack of knowledge to identify the pest and diseases were reported by 36.67 percent. The farmers knew about the major pest and diseases and managing the situation. But they don't know minor pest and diseases and having misconception about micronutrient deficiency with pest symptom.

Lack of communication and training cum demonstrations on improved practices $(35.56 \%)$ was one of the factors expressed by the farmes. The extension service should ensure the farmers applying the recommended technological packages in fields through effective training, demonstrations, field visits, monitoring, etc. The judicious application of inputs from seeding to harvesting in terms of quantity and timing will significantly contribute to reduce yield gaps and thereby increasing productivity of crops.

Lack of government credit/ subsidy $(31.11 \%)$ was expressed by the farmers as one of the factors for yield gap. Adequate subsidy and credit supplies play an important role in the productivity of crops and minimizing yield gaps. Itching in hands which reduces the picking of Bhendi fruits was felt by $27.78 \%$ 
of the farmers. The farmers sometimes delaying the harvest of Bhendi crops. By this time the bhendi get matured due to maturity they felt itching in hands while picking.

Suggestive measures to increase production and productivity of major vegetable crops in Madurai district

Yield gaps in vegetable crops between potential and farmers' yields are still substantially high due to the combination of above factors. Hence, research and extension support is necessary for narrowing technological gap and yield gap by properly addressing the constraints. The researcher should understand farmers' constraints to high productivity and accordingly modify or develop integrated technological package (appropriate variety, timely planting, fertilizer, irrigation, and pest management) for farmers for specific locations to bridge up the gaps.

Table.1 Biological and climatic factors reducing the productivity in tomato

\begin{tabular}{|c|c|c|c|c|c|}
\hline Crops & $\begin{array}{l}\text { Factors reducing the } \\
\text { productivity }\end{array}$ & $\begin{array}{c}\text { Farmers } \\
\text { Response } \\
(\%)\end{array}$ & Crops & $\begin{array}{l}\text { Factors reducing the } \\
\text { productivity }\end{array}$ & $\begin{array}{c}\text { Farmers } \\
\text { Response }(\%)\end{array}$ \\
\hline $\begin{array}{l}\text { Sunscald due to } \\
\text { high temperature }\end{array}$ & & 61.66 & $\begin{array}{l}\text { Tomato cracking } \\
\text { or Split tomato } \\
\text { problem }\end{array}$ & & 53.33 \\
\hline $\begin{array}{l}\text { Deformation of } \\
\text { tomato fruit }\end{array}$ & & 51.66 & $\begin{array}{l}\text { Blossom } \\
\text { Dropping and } \\
\text { less fruit setting } \\
\text { percentage }\end{array}$ & & 68.33 \\
\hline $\begin{array}{ll}\text { Tomato } & \text { fruit } \\
\text { zippering } & \end{array}$ & & 26.66 & $\begin{array}{l}\text { Hardness of } \\
\text { fruit/ smaller size } \\
\text { of fruit bearing }\end{array}$ & & 30.00 \\
\hline $\begin{array}{l}\text { Yellow or green } \\
\text { tomato shoulders }\end{array}$ & & 46.66 & Fruit Borer & & 70.00 \\
\hline Blossom End rot & & 33.33 & & & \\
\hline
\end{tabular}


Table.2 Biological and climatic factors reducing the productivity in Brinjal and Bhendi

\begin{tabular}{|c|c|c|}
\hline Crops & Biological Factors reducing the productivity & Farmers Response $(\%)$ \\
\hline $\begin{array}{l}\text { Brinjal } \\
\text { 1. }\end{array}$ & Fruit borer and squirrel problem & 76.66 \\
\hline 2. & & 40.00 \\
\hline 3. & Brown Streaking & 36.66 \\
\hline 4. & Small and unsized $\mathrm{f}$ & 30.00 \\
\hline $\begin{array}{l}\text { Bhendi } \\
1 .\end{array}$ & Fruit borer and powde & 50.00 \\
\hline 2. & Bhendi curling/Small size of fruit/dis coloration & 40.00 \\
\hline
\end{tabular}




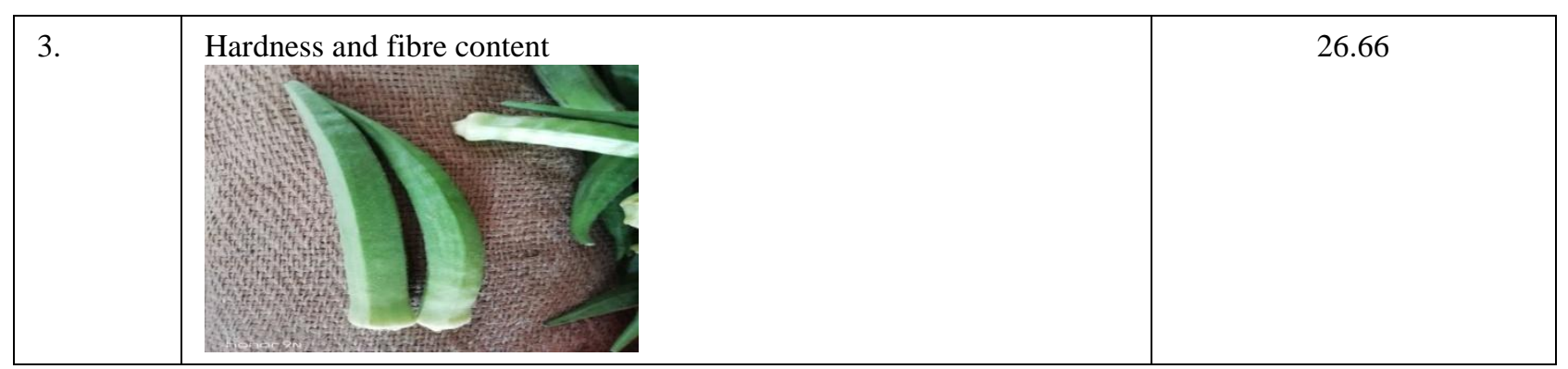

Table.3 Other factors reducing the productivity of major vegetables

\begin{tabular}{|l|l|c|}
\hline S.No & \multicolumn{1}{|c|}{ Factors } & $\begin{array}{c}\text { Farmer's } \\
\text { response (\%) }\end{array}$ \\
\hline 1. & Personal/communication/Institutional/Government & \\
\hline 2. & Lack of Knowledge to identify pest and diseases & 36.67 \\
\hline 3. & Unavailability of timely and quality inputs & 27.78 \\
\hline 4. & lack of visit by extension officials to farmers field & 42.22 \\
\hline 5. & lack of communication and training cum demonstrations on & 33.33 \\
\hline 6. & Lack of government credit/ subsidy & 35.56 \\
\hline 7. & Rise in fertilizer and pesticide prices & 31.11 \\
\hline
\end{tabular}

In the study area the biological factors which reduce the yield should properly be addressed. To mitigate the adverse effects of climatic change on productivity and quality of vegetable crops there is a need to develop sound adaptation strategies. The emphasis should be on development of production systems for improved water use efficiency adoptable to the hot and dry condition. Development of high yielding varieties tolerant to high temperature, moisture stress, salinity and climate proofing through conventional, non-conventional, biotechnology, breeding techniques are essentially required to meet these challenges. Improved nutrient-use efficiency, organic manures, bio fertilizers, bio-agents, mulching with crop residues and plastic mulches help in conserving soil moisture. Excessive soil moisture due to heavy rain becomes major problem that can be overcome by growing crops on raised beds. The extension system have to popularize the recommended technological packages in fields through effective training, demonstrations, field visits, monitoring, etc. which helps to reduce yield gaps and thereby increasing productivity of crops. It is also essential to promote collaboration with NGOs and private sector to develop appropriate technologies with a view to narrowing yield gaps

The government must strengthen efforts to ensure timely supply of adequate quantities of quality inputs to the farmers to enable them to minimize yield gap in vegetable crops. Both 
public and private sectors should play a vital role in producing and distributing appropriate inputs in time.

Resource-poor small and marginal vegetable farmers may not be able to achieve high yield. This is because these farmers are not usually able to purchase required quantities due to high cost of inputs to obtain such yield. It is, therefore, essential for the government to take steps to timely supply adequate amounts of credit or subsidy to these farmers. Farmers have very limited access to institutional credit mainly because of collateral requirement. Therefore, appropriate measures must be taken to reduce transaction costs, simplify lending procedures, revise eligibility criteria and strengthen monitoring and supervision mechanism of the credit system (Mohammad, 2011).

The Vegetable production is suffering due to lack of post-harvest technologies, inadequate storage, and transport, handling and processing which leads to wastage and value loss. The magnitude of these losses is 6-18\% in vegetables. Hence, value addition is the easiest way to reduce these losses.

The demand for ready-to-eat, easy-to-cook vegetables is increasing. Processed vegetables are very popular as it saves time, labour and having extended shelf life. In this regard, low cost vegetable processing and value addition is very important to minimize huge postharvest losses to a greater extent for nutritional security. The women in their family may be trained on value addition which they can get additional income in their leisure time.

In conclusion, the biological factors which reduces yield gap in tomato is ranging from 26.67 to 70.00 percent and for brinjal 30.00 to 76.66 and bhendi it was 26.67 to 50.00 percent. The other factors were rise in fertilizer and pesticide prices, unavailability of timely and quality inputs, lack of knowledge to identify pest and diseases, lack of communication and training cum demonstrations on improved practices were felt by 35-45 percent of the farmers as other factors for yield gap. These factors can be effectively addressed through an Integrated Crop Management (ICM) practices. Transfer of practices through extension agents could effectively help farmers minimize technology gaps and yield gaps, effective cultural practices like deep summer ploughing, seed priming, biological seed treatments, timely planting, proper seeding depth, irrigation, uniform fertilizer application, weeding, mulching, plant protection and timely harvesting help the farmers of TamilNadu to minimize the yield gap in vegetable crops.

\section{References}

Alam, J.D. and Haseen, M. S. (2011). Impact of climate change on agriculture and food security in India. Internat. J. Agric. Environ. \& Biotechnol., 2 :129-137.

Ayyogari, Kondinya, Sidhya, Palash and Pandit, M.K. (2014).Impact of climate change on vegetable cultivation - A Review, Internat. J. Agric. Environ. \& Biotechnol., 7(1): 145-155.

Bennett, M.A. 1997. Biological seed treatments for improved corn germination and emergence. In: Annual Asta Corn and Sorghum Research Conference, 51, 1997. Proceedings. Washington: American Seed Trade Association, 1997. Pp. 200-211.

Mohammad (2011) Bangladesh Causes of Yield Gaps and Strategies for Minimizing the Gaps in Different Crops of Bangladesh J. Agril. Res. 36(3): 469476, September 2011

Rachna Singla (2016) Role of women in vegetable production in District Patiala published in Asian J. Home Sci., 11(2) 
Dec., 2016: Pp. 336, Hind Institute of Science and Technology.

Stapleton, J.J., Prather, T.S., Mallek, S.B., Ruiz, T.S., Elmore, C.L., 2000. High temperature solarization for weed control in container soil and potting mixes. Proceedings of the California
Weed Science Society, Vol. 52, 204207.

Sudhirsingh (2015) Value Addition of Vegetable Crops Indian Institute of Vegetable Research, IIVR Technical Bulletin, Jakhini (Shahanshapur), Varanasi, India.

\section{How to cite this article:}

Janaki Rani, A. 2020. Factors Responsible for the Yield Gap in Vegetable Cultivation and Measures to Increase the Productivity in Tamil Nadu, India. Int.J.Curr.Microbiol.App.Sci. 9(09): 1017-1025. doi: https://doi.org/10.20546/ijcmas.2020.909.126 